\title{
Managing Protected Areas under Climate Change-Diverse Management for Biodiversity
}

\author{
Sven Rannow $\cdot$ Michael Förster
}

Received: 16 January 2014/ Accepted: 11 July 2014/Published online: 24 July 2014

(C) Springer Science+Business Media New York 2014

\begin{abstract}
Keywords Conservation management $\cdot$ Climate adaptation - Monitoring - Assessing sensitivity · Management practices - Legal and policy advice
\end{abstract}

The loss of species and habitats is one of the major threats for biodiversity. Current drivers are anthropogenic factors such as the intensification of agriculture, urbanization, and infrastructure development. However, climate change adds to the mix and reinforces the negative effects on biodiversity. It alters abiotic habitat conditions, such as water balance, shifts phenology and the distribution of species, affects habitat structures and changes ecosystem functions and services (Bellard et al. 2012). To address these changes, we need improved institutional cooperation, expanded spatial and temporal observation, better models to project the effect of climate change scenarios, and greater effort to address multiple threats and global change drivers simultaneously within conservation management on different planning scales (Heller and Zavaleta 2009).

Climate-adapted conservation requires continuous adaptation to changing climate and its ecological consequences. Inter- and transdisciplinary research on cross-cutting themes is necessary to provide mutual learning among all actors and the development of effective strategies (Raymond et al. 2013). From 24 to 26 September 2012, the International Conference on Managing Protected Areas under Climate

S. Rannow $(\bowtie)$

Elbe-Brandenburg River Landscape Biosphere Reserve, Neuhausstraße 9, 19322 Rühstädt, Germany

e-mail: sven.rannow@gmx.de

\section{Förster}

Geoinformation in Environmental Planning Lab, Technische Universität Berlin, Sekr. EB 5, Str.d. 17. Juni 145, 10623 Berlin, Germany
Change (IMPACT) was held in Dresden (Germany) to meet the growing need for good-practice examples of climateadapted conservation management. More than 120 experts in the field of nature conservation from over 30 countries joined the conference. Participants represented research institutions, national ministries and conservation agencies, NGOs, and managers from protected areas like Nature Parks, Biosphere Reserves, and National Parks. The event provided a platform for dialog between scientists and conservation managers to develop a better understanding of the complex impacts of climate change on biodiversity at the local level and the means to adapt management in protected areas accordingly.

This Special Feature covers selected contributions from the conference and tries to wrap up the main results from the management perspective. The need for further research and open questions is also highlighted. The topics covered in this Special Feature are focused on current as well as future management practices, legal aspects, policy recommendations, and supporting adaptation to climate change.

Three contributions address current and future management practices:

- Ivajnsic and Kaligaric (2014) evaluate three potential adaptation measures to protect coastal wetlands from sea level rise. They use a habitat transition model to compare the effect of buffer zones, the construction of artificial islets, and permanent, artificial sea-barriers on the preservation of two low-lying wetlands at the Adriatic coast.

- Ausden (2013) gives a very practical example of climate change adaptation by evaluating the management plans of the nature reserves of the Royal Society for the Protection of Birds in the UK. In this article, the main types of measures which are expected to facilitate 
adaptation of wildlife management to climate change are identified.

- Macgregor and van Dijk (2014) investigate how adaptation to climate change in protected areas has been implemented in south-east England. They used written questionnaires and semi-structured interviews to collect information from managers of a range of different conservation areas. The authors identified a set of major themes, among them a growing awareness of the need to take a strategic and large-scale approach to climate adaptation.

Two papers are related to legal and policy recommendations to support adaptation to climate change:

- Cliquet (2014) searches international and European regulations on protected areas and climate change for evidence about whether the legal framework is capable of dealing with the required changes of a climate-adapted management. In order to adapt the legal regulations to increasing dynamics in climatic conditions, more flexibility in their use and interpretation is recommended. However, this flexibility must not be understood as 'legal' flexibility, in the sense of weakening nature conservation provisions.

- Rannow et al. (2014) present an overview on challenges and priorities for the adaptation of conservation management as discussed at the IMPACT 2012. The paper summarizes the main issues for implementing adaptation that emerged from the conference. This includes a series of conclusions and recommendations on monitoring, assessment of species and habitat sensitivity to climatic changes, current and future management practices, as well as legal and policy aspects.

These contributions in this Special Feature illustrate how climate adaptation can be integrated in conservation management to help conservation managers today make decisions about climate impacts of the future.

We wish to thank all the participants and contributors of the IMPACT 2012. Their input and vital discussions during the conference made this Special Feature possible. The IMPACT was part of the project "Adaptive Management of Climate-induced Changes of Habitat Diversity in Protected Areas" (HABIT-CHANGE), which was implemented within the INTERREG IV B CENTRAL EUROPE program during 2010-2013. We would like to thank all project partners as well as our funding organization of the German Research Foundation (DfG) and the European Rural Development Fund (ERDF). Finally, we would like to thank the all reviewers who were involved in the production of this Special Feature for their thorough and timeconsuming work within the review process.

\section{References}

Ausden (2013) Climate change adaptation: putting principles into practice. Environ Manage. doi:10.1007/s00267-013-0217-3

Bellard C, Bertelsmeier C, Leadley P, Thuiller W, Courchamp F (2012) Effects of climate change on the future of biodiversity. Ecol Lett 15:365-377

Cliquet A (2014) International and European law on protected areas and climate change: need for adaptation or implementation? Environ Manage. doi:10.1007/s00267-013-0228-0

Heller NE, Zavaleta S (2009) Biodiversity management in the face of climate change: a review of 22 years of recommendations. Biol Conserv 142:14-32

Ivajnsic D, Kaligaric M (2014) How to preserve coastal wetlands threatened by climate change-driven rises in sea level? Environ Manag. doi:10.1007/s00267-014-0244-8

Macgregor NA, van Dijk N (2014) Adaptation in practice: how managers of nature conservation areas in eastern England are responding to climate change. Environ Manag. doi:10.1007/ s00267-014-0254-6

Rannow S, Macgregor NA, Albrecht J, Crick HQP, Heiland S, Janauer G, Morecroft MD, Neubert M, Sarbu A, Sienkiewicz J (2014) Managing Protected Areas under Climate Change challenges and priorities. Environ Manag. doi:10.1007/s00267014-0271-5

Raymond C, Peterson D, Rochefort R (2013) The North Cascadia Adaptation Partnership: a science-management collaboration for responding to climate change. Sustainability 5:136-159. doi:10. $3390 /$ su5010136 